\title{
Impacts of cell phone use on driving safety and drivers' perception of risk
}

\author{
Dazhi Sun ${ }^{1} \cdot$ Anxi Jia ${ }^{1}$
}

Received: 30 October 2015/Revised: 20 December 2015/ Accepted: 16 February 2016/Published online: 18 April 2016

(C) The Author(s) 2016. This article is published with open access at Springerlink.com

\begin{abstract}
In this study, the factors influencing phone-related driving safety and drivers' perceptions of cell phone usage were analyzed. A representative sample of more than 500 licensed drivers in Texas who own a cell phone was interviewed based on a well-design questionnaire. Logistic regression model showed that the impact of using cell phone on driving safety varies depending on the characteristics of drivers, such as gender, age, driving experience, and use intensity. Additionally, the results indicated that the strong determinants of phone-related hazard are different from that of phone-related accidents. Regarding the drivers' perception of cell phone usage, there are two key findings. First, there is no explicit belief among the drivers about whether cell phone usage impairs driving safety regardless of the drivers' age, gender, driving education experience etc. Second, most of drivers have not realized that cell phone use while driving would increase their perception reaction time. Based on the analysis of these results, implications of cell phone use on driving safety along with some safety countermeasures, such as selective bans and non-cell phone zones, are discussed in the paper.
\end{abstract}

Keywords Cell phone - Phone-related hazard - Phonerelated accident

\section{Introduction}

National Highway Traffic Safety Administration [1] reported that almost $80 \%$ of crashes and $65 \%$ of nearcrashes involved some form of driver inattention, among

Dazhi Sun

dazhi.sun@tamuk.edu

1 Texas A\&M University-Kingsville, Kingsville, TX, USA which cell phones use is the most common distraction. Cellular Telecommunications \& Internet Association estimated that in the United States over 236 million people subscribed to such wireless communication devices as cell phones as of May 2007, compared with approximately 4.3 million in 1990. Increased reliance on cell phones has inevitably led to a rise in the number of people who use the devices while driving. NHTSA [2] had estimated approximately 974,000 drivers on the road nationwide at any time during the day using a handheld cell phone. In recent years, cell phone use while driving has led to an obvious concern about driving safety.

\subsection{Current research approaches and results}

In general, there are three major research methods currently employed to study the effects of cell phone use on driving safety. The first is to establish a statistical association between cell phone use and accidents using survey data [3-6]. The second is simulator based or on-road controlled experiments $[7,8]$. The third method mainly depends on accident statistics from police reports, aggregate crash, and cell phone statistics [9, 10]. Hahn and Dudley [11] and McCartt et al. [12] examined all of the methods and found that each approach has its own shortcomings. The key findings and their shortcomings of each method are summarized in the following.

\subsubsection{Survey}

The survey data are commonly collected through personal interview, telephone interview, and internet-based questionnaires. Redelmeier and Tibshirani [10] concluded that the risk of a collision when using a cell phone was four times higher than the risk when a cell phone was not being 
used. Pöysti et al. [13] reported that some factors, such as drivers' age, amount of phone usage, and occupational position, were related to phone-related hazards. Hahn and Prieger [14] found that there is no significant effect of hands-free or handheld cell phone use on accidents. Regarding the survey method, however, the sample selection and the dishonest answers to the sensitive questions, such as whether they were involved in accidents because of cell phone use, may bias the result.

\subsubsection{Simulation and experiment}

In recent years, driving simulation and an on-road controlled experiment are quite prevalent methods to study the impacts of cell phone usage while driving. Reed and Green [7] provided experimental evidence of negative effects on lane keeping, steering performance, and accelerator control. Strayer and Johnston [15] reported that drivers engaged in cell phone conversations missed twice as many traffic signals and had slower reaction times. More recently, through a new study, Strayer confirms that the reaction time of cell phone users increases dramatically, increasing the risk of accidents and tying up traffic in general. The driving simulation or on-road controlled experiments could also bias the result due to the experimental nature of data collection effort, which has less accuracy than real-world situations. Moreover, it is difficult to obtain representative samples of drivers in conducting such simulation or experiment. Haigney and Westerman [16] insist on the need to specify the conditions in which the experiments are performed and to restrict their conclusions to those conditions.

\subsubsection{Accident statistics}

It is inevitable to study the drivers' crash history for evaluating the crash risk associated with phone use. Unfortunately, most states in U.S. do not provide data elements in the crash report forms recording drivers' cell phone use. Although the characteristics of cell phone-related crash were examined in some research (Goodman et al. [17], Huang and Stutts [18]), McCatt [12] concluded that police reports would not be appropriate in assessing the role of phone use in crashes because the data on phone use are unreliable. In order to fix this problem, some research used the cell phone company billing records to verify cell phone use. The most representative study was conducted by McEvoy et al. [19] in Australia. They found that a driver's use of a cell phone up to 10 min before a crash was associated with a fourfold increased likelihood of a serious crash. However, another problem is that accident statistic reports may overwhelmingly limit the sample to drivers who had accidents and may overestimate the impact of usage of cell phones on accidents. A recent research, by Hahn and Prieger [14], implies that previous estimates of the impact of cell phone use on risk for the population may be overstated by about one third.

\subsection{The objective of this study}

The objective of this study is to evaluate the impacts of cell phone use on driving safety and drivers' perception in Texas. Although it is very clear that cell phone use degrades driving performance and safety based on previous studies, it is not clear whether its impacts will vary with the characteristics of drivers, such as gender, driving experience, driving behavior, and cell phone use intensity. Bailey [20] and Nunes and Recarte [21] indicate that cell phone use while driving increases the overall level of cognitive, and sometimes physical, demand of drivers. This result is consistent with the finding that, in this circumstance, both heart rate and self-report workload increase which implies that safety margins are reduced when talking on a mobile phone, because drivers have less spare processing resources to allocate to driving operation. The hypothesis of this paper is that cell phone use may generate different impacts on different driver groups, because driving workload among different groups could be varied. Another difference from previous studies is that drivers' perceptions of the impacts of cell phone use will be examined and compared in this study.

\section{Method and data collection}

This study was conducted in Texas, with no regulations against using cell phone while driving. Based on careful comparison of the three prevalent approaches discussed in previous section, personal interview survey is finally selected as the data collection method. The driving simulation and on-road experiment are not suitable for evaluating the accident risk of cell phone use due to its experimental nature and unrepresentative sample. Regarding the accident statistics method, although the cell phone company's billing records could help verify the phone use related to crashes, such records have been unavailable in the United States. Among the three options of survey methods, personal interview and internet-based questionnaires could be conducted in an anonymous manner. Chang and Krosnick [22] indicate that anonymous survey can impressively reduce the effect of "dishonest" answers on the survey's accuracy, compared with telephone surveys. Although the personal interview survey may involve more cost, it offers three major advantages compared with internet-based survey. First, people will usually respond when confronted in person. Second, the sample may be 
more representative than internet-based surveys because the latter limits the sample to the internet-users. In addition, the interviewer can note specific reactions and eliminate misunderstandings about the questions asked.

A well-designed interview questionnaire was developed to collect expected data. This questionnaire (see Table 1) consists of four question categories: basic personal information, cell phone use information, crash or dangerous driving history, and drivers' perceptions. Among the questionnaire, the items concerning that an accident or a hazard situation happened when there's cell phone use are designed as the dependant variables. Marshall and Rodney [23] suggest dependence on the observation that if the cell phone usage increases accident risk, then the driver is more likely to be on the phone at the time of the crash than during the earlier reference period. The drivers' age, driving experience, gender, frequency of cell phone use, text messaging, and driving speed are selected as the independent variables. The items concerning perception are designed to reveal the motorists' beliefs or attitude on what impact, if any, cell phone usage has on their driving behavior and safety.

The interviewers are composed of 50 engineering students, who are thoroughly trained to correctly state and explain the question. In order to obtain the sample as representative as possible, the student went to gas stations and public parking lots at the library and shopping marts to conduct the interview and record the responses. The respondents are randomly selected by the interviewers from 8:00 a.m to 8:00 p.m. More than 1,000 questionnaire sheets were completely finished by the respondents and about 300 drivers were not willing to respond or finish the interview at last. The response rate of this study is about $75 \%$. After the deletion of problematic questionnaires, the sample finally consisted of 942 participants $(57 \%$ male and $43 \%$ female) who have valid driver license. Their ages ranged from 16 to 55 (25\% in 16-20, $24 \%$ in $21-25$, $22 \%$ in $26-30$, and $29 \%$ above 30 ). The sample contains drivers who had accidents and who did not, drivers who use a cell phone as well as drivers who do not.

In this study, two separate logistic regression analyses were made. The first is to study the hazard situation experienced while using the cell phone, while the second is for the accidents that happened when they were using cell phone. Chi-square test was used to examine the independence between the dependant and independent variables. For the analysis of drivers' perceptions, unpaired $t$ test was used to compare the mean of the drivers' perceptions. All results are reported at 0.05 confident intervals.

\section{Results}

The result of this study indicates that there are 862 drivers $(87.7 \%)$ who ever use a cell phone while driving and 116 $(12.3 \%)$ who do not. Among the 862 drivers who use cell phone while driving, 466 are male drivers (54\%) and 396 are female drivers $(46 \%)$.

Table 1 Items of questionnaire

\begin{tabular}{|c|c|c|}
\hline Domain & Subcategory & Questions \\
\hline \multirow[t]{4}{*}{ Basic information } & Age & What is your age? \\
\hline & Gender & What is your gender? \\
\hline & Driving experience & How many years driving experience do you have? \\
\hline & Driving habits & Do you typically drive under, at, or above the posted speed limit? \\
\hline \multirow[t]{3}{*}{ Cell phone use } & Usage & Do you ever drive and use cell phone simultaneously? \\
\hline & Intensity & Estimate the percentage of time you spend on cell phone use while driving? \\
\hline & Text message & Do you ever text message while driving? \\
\hline \multirow[t]{5}{*}{ Crash history } & $\#$ of Accidents & How many accidents have you had in last year? \\
\hline & Cell phone related & Were any of these accidents related to your cell phone use? \\
\hline & & If YES, how many of them related to cell phone use? \\
\hline & Dangerous driving & Have you ever found yourself failing to yield or stop due to using cell phone? \\
\hline & & $\begin{array}{l}\text { Have you ever had to make a sudden evasive maneuver to avoid being in an accident while you } \\
\text { were driving and using cell phone? }\end{array}$ \\
\hline \multirow[t]{4}{*}{ Perception } & & Most people can carry on a conversation on their cell phone and still drive safely \\
\hline & & Cell phones are more beneficial to drivers than they are harmful \\
\hline & & Using a hands-free device with a cell phone is much safer than using a handheld cell phone \\
\hline & & Using a cell phone while driving increases the perception reaction time of the driver \\
\hline
\end{tabular}

The respondents were asked to rate their opinions on the perception part on a scale of $0-10$, where 0 means "Completely disagree" and 10 means "completely agree" 


\subsection{Phone-related hazards}

About $60 \%$ of cell phone-using drivers admitted having experienced hazard traffic situations while using a cell phone in the last 12 months. The hazard situation experienced while using the cell phone, which is defined as sudden evasive maneuver to avoid being in an accident and failing to stop at signal or stop sign, had been clearly explained to the interviewers by the students. The logistic regression (Table 2) showed that whether the drivers experienced a hazard situation while using a cell phone depends on gender, using frequency, texting message, and driving speed. Female drivers reported the hazard experience two times more than their male counterpart. The more frequently the drivers use their cell phone, the more likely they have experience hazard situations. For instance, the drivers who spend more than $60 \%$ of driving time on cell phone use reported the hazard experience about 2.5 times more than the ones who only spend $<20 \%$. The drivers who use the service of text message reported the hazard situation three times more than the ones who do not use the service but use cell phone while driving. As expected, the

Table 2 Summaries of logistic regression analyses for hazard situation while using cell phone

\begin{tabular}{|c|c|c|c|c|}
\hline Predictor & & $B$ & $\begin{array}{l}\text { Odds } \\
\text { ratio }\end{array}$ & Significance \\
\hline \multirow[t]{2}{*}{ Gender } & Male Ref. & & & \\
\hline & Female & 0.6058 & 1.833 & 0.0011 \\
\hline \multirow[t]{6}{*}{ Age } & $40+$ Ref. & & & \\
\hline & $16-20$ & 0.1404 & 1.151 & 0.6956 \\
\hline & $21-25$ & 0.0529 & 1.054 & 0.1418 \\
\hline & $26-30$ & 0.0605 & 1.062 & 0.2162 \\
\hline & $31-35$ & -0.2118 & 0.809 & 0.8285 \\
\hline & $36-40$ & 0.1050 & 1.111 & 0.5422 \\
\hline \multirow{4}{*}{$\begin{array}{l}\text { Driving } \\
\quad \text { experience }\end{array}$} & $10+$ Ref. & & & \\
\hline & $0-2$ & 0.1500 & 1.162 & 0.5927 \\
\hline & $3-5$ & 0.1022 & 1.108 & 0.4571 \\
\hline & $6-10$ & -0.1578 & 0.854 & 0.1226 \\
\hline \multirow[t]{5}{*}{ Speeding } & $\begin{array}{l}\text { Above } 10+ \\
\text { Ref. }\end{array}$ & & & \\
\hline & Below & -0.5253 & 0.591 & 0.0039 \\
\hline & At & -0.3369 & 0.714 & 0.0372 \\
\hline & Above $0-5$ & -0.1461 & 0.864 & 0.9683 \\
\hline & Above 5-10 & -0.0516 & 0.950 & 0.2755 \\
\hline \multirow[t]{4}{*}{ Frequency } & $<20 \%$ Ref. & & & \\
\hline & $<40 \%$ & 0.6532 & 1.922 & $<.0001$ \\
\hline & $<60 \%$ & 0.7293 & 2.074 & $<.0001$ \\
\hline & $60 \%+$ & 0.9462 & 2.576 & $<.0001$ \\
\hline \multirow[t]{2}{*}{ Text } & 0 Ref. & & & \\
\hline & 1 & 1.0403 & 2.830 & $<.0001$ \\
\hline
\end{tabular}

drivers who typically drive at a higher speed reported more hazard situations experienced while using a cell phone. This is in line with previous results, which suggest that cell phone use increases the overall level of cognitive, and sometimes physical, demand experienced by drivers [24], while driving at a higher speed also increases the resources demanded for the overall driving task [25-27].

\subsection{Phone-related accidents}

The logistic regression (Table 3) showed that whether the drivers experienced an accident while using a cell phone depended on age, driving experience, driving speed, and using frequency. Young and inexperienced drivers are more likely involved in accidents when they were using a cell phone than the older and experienced drivers. Similar to the analysis of hazard situation, the drivers who typically drive at a higher speed and use the cell phone more frequently reported more accidents experienced while using a cell phone. There is no significant difference between male and female drivers in terms of accidents experienced while using a cell phone.

The above analysis suggests several variables could be used to predict the hazard situation or accidents experienced while using the cell phone. However, it is possible that not of all them are the strong determinants of phonerelated hazards or accidents, if there were correlations between these variables. Table 4 shows the correlations between the six variables. Age has strong correlations with driving experience, driving speed, and text messaging: young drivers definitely have less driving experience, typically drive at higher speed, and are more likely to use the cell phone frequently and the text message service. Female drivers are more likely to use the cell phone frequently and the text message service than males. The drivers, who typically travel at higher speed, reported more use frequency and use of text message service. Based on the forward logistic regression model, the final determinants are use frequency $(P$ value $=0.000)$ and text message $(P$ value $=0.015)$ for phone-related hazards. For the phone-related accidents, driving experience $(P$ value $=0.001)$ and use frequency $(P$ value $=0.038)$ are selected as the strong determinants.

\subsection{Drivers' perception of the effects of cell phone use}

This research also studied the differences in the perception of the effects of cell phone use on safety. The respondents were asked to rate their opinion on four cell phone use related driving safety statements (see Table 1). After that, the respondents are categorized into five different groups: (1) drivers taking driver education class or not; (2) male 
and female drivers; (3) drivers using cell phone while driving and not; (4) drivers involved in accidents or not; and (5) novice drivers (0-2) and experienced drivers $(3+)$ drivers. In each group, the differences of the perception are analyzed using unpaired $t$ test, which is shown in Table 5.

Table 3 Summaries of logistic regression analyses for accidents while using cell phone

\begin{tabular}{|c|c|c|c|c|}
\hline Predictor & & $B$ & $\begin{array}{l}\text { Odds } \\
\text { ratio }\end{array}$ & Significance \\
\hline \multirow[t]{2}{*}{ Gender } & Male Ref. & & & \\
\hline & Female & 0.1074 & 1.113 & 0.5573 \\
\hline \multirow[t]{6}{*}{ Age } & $40+$ Ref. & & & \\
\hline & $16-20$ & 0.5319 & 2.169 & 0.0196 \\
\hline & $21-25$ & 0.4489 & 1.567 & 0.0009 \\
\hline & $26-30$ & 0.7745 & 1.702 & 0.0339 \\
\hline & $31-35$ & 0.2343 & 1.264 & 0.1626 \\
\hline & $36-40$ & 0.2183 & 1.244 & 0.1229 \\
\hline \multirow{4}{*}{$\begin{array}{l}\text { Driving } \\
\quad \text { experience }\end{array}$} & $10+$ Ref. & & & \\
\hline & $0-2$ & 0.8035 & 2.233 & 0.0070 \\
\hline & $3-5$ & 0.4420 & 1.556 & 0.0026 \\
\hline & $6-10$ & 0.5369 & 1.711 & $<.0001$ \\
\hline \multirow[t]{5}{*}{ Speeding } & $\begin{array}{c}\text { Above } 10+ \\
\text { Ref. }\end{array}$ & & & \\
\hline & Below & -0.9075 & 0.404 & 0.0271 \\
\hline & At & -0.5082 & 0.602 & 0.0491 \\
\hline & Above $0-5$ & -0.3261 & 0.722 & 0.0620 \\
\hline & Above 5-10 & -0.2676 & 0.765 & 0.0857 \\
\hline \multirow[t]{4}{*}{ Frequency } & $<20 \%$ Ref. & & & \\
\hline & $<40 \%$ & 0.0803 & 1.084 & 0.4157 \\
\hline & $<60 \%$ & 0.3405 & 1.406 & 0.0040 \\
\hline & $60 \%+$ & 0.3595 & 1.433 & 0.0256 \\
\hline \multirow[t]{2}{*}{ Text } & 0 Ref. & & & \\
\hline & 1 & -0.0745 & 0.928 & 0.6855 \\
\hline
\end{tabular}

\subsubsection{Drivers taking driver education class versus drivers not}

In Texas, all new drivers under 18 must complete an approved driver education course before they can be licensed. Moreover, the drivers who have been involved in accidents or issued tickets could also take the driver education course to keep their insurance rates reasonable or reduce the fines. According to the results of the survey, however, there are no statistically significant difference of perception between the drivers who had taken driving education classes and the drivers who had not. The two groups have the same neutral attitudes about the effects of cell phone use on their driving safety. For the questions regarding PRT, neither of the two groups is sure whether cell phone use impairs their PRT. Both of them are inclined to agree that a hands-free device is much safer than a handheld device.

\subsubsection{Novice driver versus experienced driver}

No statistically significant difference has been found about the perception between the novice drivers and their experienced counterparts, according to the $P$ values of the $t$ test shown in Table 5. Moreover, the results show that both of them are not very clear whether cell phone use has affected their driving safety. According to the mean rates, the novice drivers are more likely to underestimate the effect of cell phone use on PRT than the experienced drivers.

\subsubsection{Male versus female}

The $t$ test results show that there is no statistically significant difference of perception by gender. For statement 3 (hands-free vs. handheld), the mean rates of female drivers

Table 4 Correlations between the variables

\begin{tabular}{|c|c|c|c|c|c|c|}
\hline & Age & Gender & Drive experience & Speeding & Frequency & Text \\
\hline \multirow[t]{2}{*}{ Age } & \multirow[t]{2}{*}{1.00000} & -0.14348 & 0.65881 & -0.13944 & -0.03482 & -0.23233 \\
\hline & & 0.0014 & $<.0001$ & 0.0020 & 0.4413 & $<.0001$ \\
\hline \multirow[t]{2}{*}{ Gender } & -0.14348 & 1.00000 & -0.20080 & -0.03672 & 0.19819 & 0.12680 \\
\hline & 0.0014 & & $<.0001$ & 0.4169 & $<.0001$ & 0.0049 \\
\hline \multirow[t]{2}{*}{ Drive experience } & 0.65881 & -0.20080 & 1.00000 & -0.01773 & 0.02929 & -0.12186 \\
\hline & $<.0001$ & $<.0001$ & & 0.6952 & 0.5174 & 0.0069 \\
\hline \multirow[t]{2}{*}{ Speeding } & -0.13944 & -0.03672 & -0.01773 & 1.00000 & 0.21592 & 0.17643 \\
\hline & 0.0020 & 0.4169 & 0.6952 & & $<.0001$ & $<.0001$ \\
\hline \multirow[t]{2}{*}{ Frequency } & -0.03482 & 0.19819 & 0.02929 & 0.21592 & 1.00000 & 0.30159 \\
\hline & 0.4413 & $<.0001$ & 0.5174 & $<.0001$ & & $<.0001$ \\
\hline \multirow[t]{2}{*}{ Text } & -0.23233 & 0.12680 & -0.12186 & 0.17643 & 0.30159 & 1.00000 \\
\hline & $<.0001$ & 0.0049 & 0.0069 & $<.0001$ & $<.0001$ & \\
\hline
\end{tabular}


are still greater than male by $7.7 \%$, although these differences are not statistically significant.

\subsubsection{Drivers using cell phone while driving versus drivers not}

Statistically significant differences have been found about the perception between the drivers who use a cell phone while driving and the ones who do not. The results indicate that the drivers who do not use a cell phone are much more inclined to agree that cell phone use while driving could impair the driving safety than the drivers who use. However, the former group is more likely to underestimate the effect of cell phone use on the PRT than the later group. For the hands-free and handheld issue, the drivers who use a cell phone are more inclined to agree that the hands-free device is much safer.

\subsubsection{Drivers involved in cell phone-related accidents versus drivers not}

There is no statistically significant difference of perception between the drivers who have been involved in cell phonerelated accidents and the ones who have not. Although the former group has been involved in cell phone-related accidents, they have the similar attitude as the latter group about the effects of cell phone use on driving safety. Paradoxically, the mean rates of statement 1 and statement 2 of the former group are greater than the rates of the latter group by $9.2 \%$ and $22.6 \%$, respectively. This finding indicates that the drivers who have been involved in some cell phone-related accidents usually are those who are more likely to underestimate the effect of talking on cell phone on driving safety.

\section{Discussion and recommendation}

The results of this study show that frequency use and text messaging are two strong determinants of a phone-related hazard. When it comes to the phone-related accident level, however, the determinant variable is driving experience and use frequency. Cell phone usage while driving could increase the likelihood of both traffic hazards and accidents; however, whether the phone-related accidents happen also depends on the drivers' driving experience. Moreover, driving experience contributes more than use frequency for the phone-related accidents according to the regression model. That means that using a cell phone is not threatening the safety of all driver groups equally: cell phone usage will result in phone-related accident more easily for novice drivers than experienced ones. Even for novice drivers, about $50 \%$ of them have experienced phone-related hazards, while only $6 \%$ of them have phone-related accidents. This indicates that the safety situation with a cell phone is not extremely serious. The potential phone-related accident risks have been controlled at the acceptable level and have not increased in line with the rapid growth of cell phone usage. Some authors have also suggested that most drivers can manage with their mobile phone while driving (Mikkonen and Backman [28]). However, it does not mean the phone-related accidents should be overlooked, considering that driving the car is the major task, while using cell phones is just a

Table 5 Perceptions of different groups of the effects of cell phone use

\begin{tabular}{|c|c|c|c|c|c|}
\hline Category & Rate & Statement 1 & Statement 2 & Statement 3 & Statement 4 \\
\hline Take class & Mean $(\mathrm{R})$ & 5.00 & 4.48 & 5.09 & 4.20 \\
\hline \multirow[t]{2}{*}{ Not take class } & Mean $(\mathrm{R})$ & 5.12 & 4.36 & 4.70 & 3.92 \\
\hline & $P$ value & 0.670 & 0.670 & 0.197 & 0.398 \\
\hline Male & Mean $(\mathrm{R})$ & 5.02 & 4.40 & 4.72 & 3.99 \\
\hline \multirow[t]{2}{*}{ Female } & Mean $(\mathrm{R})$ & 5.08 & 4.49 & 5.24 & 4.22 \\
\hline & $P$ value & 0.828 & 0.747 & 0.067 & 0.474 \\
\hline Use cell phone & Mean $(\mathrm{R})$ & 5.25 & 4.70 & 5.89 & 4.25 \\
\hline \multirow[t]{2}{*}{ Not use cell phone } & Mean $(\mathrm{R})$ & 3.64 & 2.55 & 2.90 & 2.95 \\
\hline & $P$ value & 0.000 & 0.000 & 0.005 & 0.008 \\
\hline Have cell phone-related accidents & Mean $(\mathrm{R})$ & 5.48 & 5.37 & 4.44 & 4.44 \\
\hline \multirow[t]{2}{*}{ Not have cell phone-related accidents } & Mean $(\mathrm{R})$ & 5.02 & 4.38 & 4.98 & 4.07 \\
\hline & $P$ value & 0.448 & 0.091 & 0.442 & 0.565 \\
\hline Novice drivers & Mean $(\mathrm{R})$ & 5.17 & 4.41 & 4.80 & 3.80 \\
\hline \multirow[t]{2}{*}{ Experienced driver } & Mean (R) & 4.94 & 4.46 & 5.07 & 4.35 \\
\hline & $P$ value & 0.369 & 0.852 & 0.352 & 0.083 \\
\hline
\end{tabular}


secondary task and may result in additional accident risk. Therefore, traffic safety communities should still enhance the management and education to reduce or prevent the phone-related accidents, especially for the specific risk groups, novice drivers.

According to the results, novice drivers are more likely to be involved in phone-related accidents than experienced ones. Unfortunately, there is no significant difference between novice drivers and experienced drivers about their perception of the impact of cell phone use on travel safety. This is an obvious inconsistency between their actual performance and their subjective perception. The cell phone usage effects on gender only appeared at the phonerelated hazard level. Compared to female drivers, the male drivers are found to be more likely to experience cell phone-related hazards. Concerning the phone-related accidents, however, there is no significant difference between male and females.

Another interesting finding is that current driving education classes do not show significant improvement on the drivers' perception of the effects from cell phone use. The drivers who have taken a driving class do not exhibit expected right perception of the impact of cell phone use on their driving safety as well as PRT. Their perception of effects is quite similar to the drivers who have never taken these classes. To reduce the cell phone-related accident risk, current driving education programs should be enhanced to improve the awareness of impairing effects of using a cell phone while driving, especially for the specific risk groups, i.e., young drivers or novice drivers.

Besides negative effects, it is undoubted that cell phone use could also provide some benefits to drivers, such as emergency calls to report accidents immediately. Moreover, in most cases, the legislation only restricts the use of handheld phones while driving. In the U.S., New York, New Jersey, Washington, D.C. and many municipalities fully outlawed in-vehicle handheld phone use. However, this restriction may be problematical itself. For example, Strayer et al. [8] and Ishigami [29] concluded that allowing hands-free cell phone use will have very little effect on reducing the driver distractions and accident risk. Therefore, it seems unreasonable to ban all drivers from using their cell phones while driving. It could be a feasible solution to selectively ban vulnerable drivers to use cell phones. For instance, drivers with $<2$ years of driving experience, and the drivers who have been involved in cell phone-related accidents in the last 1 or 2 years could be considered as the vulnerable drivers. In addition, non-cell phone zone would be another reasonable, possible remedy to address the cell phone-related safety issues. The qualified locations for the non-cell phone zone could include some roadway segments requiring heavy driving workload, such as highway work zones, busy intersections, and high crash risk locations with constrained sight distance. In all these cases, there will obviously be enforcement related issues.

Besides the legislative efforts, insurance companies could play a vital role to alleviate the increasing impairing effects of cell phone use on driving safety. For example, in the United Kingdom and Germany, insurance companies are allowed to cancel the drivers' insurance coverage if they are involved in a crash while talking on phone. The impact of such measures by insurance companies will have important policy implications in the country too.

Open Access This article is distributed under the terms of the Creative Commons Attribution 4.0 International License (http:// creativecommons.org/licenses/by/4.0/), which permits unrestricted use, distribution, and reproduction in any medium, provided you give appropriate credit to the original author(s) and the source, provide a link to the Creative Commons license, and indicate if changes were made.

\section{References}

1. National Highway Traffic Safety Administration (2006) The impact of driver inattention on near-crash/crash risk: an analysis using the 100-car naturalistic driving study data. Department of Transportation, NHTSA, Washington

2. National Highway Traffic Safety Administration (2004) Traffic safety facts 2002: a compilation of motor vehicle crash data from the fatality analysis reporting system and the general estimates system. U.S. Department of Transportation, NHTSA, National Center for Statistics and Analysis, Washington

3. Dreyer NA, Loughlin JE, Rothman KJ (1999) Cause-specific mortality in cellular telephone users. J Am Med Assoc 282(19):1814-1815

4. Redelmeier DA, Tibshirani RJ (1997) Association between cellular-telephone calls and motor vehicle collisions. N Engl J Med 336(7):453-458

5. Violanti JM, Marshall JR (1996) Cellular phones and traffic accidents: an epidemiological approach. Accid Anal Prev 28(2):265-270

6. Violanti JM (1998) Cellular phones and fatal traffic collisions. Accid Anal Prev 30(4):519-524

7. Reed MP, Green PA (1999) Comparison of driving performance on road and in a low-cost simulator using a concurrent telephone dialing task". Ergonomics 42(8):1015-1037

8. Strayer DL, Crouch D, Drews FA (2006) A comparison of the cell-phone driver and the drunk driver. Hum Factors 48:381-391

9. Laberge-Nadeau C, Maag U, Bellavance F, Lapierre S, Desjardins D, Messier S, Saidi A (2003) Wireless telephones and the risk of road crashes. Accid Anal Prev 35:649-660

10. Redelmeier DA, Tibshirani RJ (1997) Interpretation and bias in case-crossover studies. J Clin Epidemiol 50(11):1281-1287

11. Hahn RW, Dudley PM (2002) The disconnect between law and policy analysis: a case study of drivers and cell phones. Adm Law Rev 55(1):127-185

12. McCartt Anne T, Hellinga Laurie A, Bartiman Keli A (2006) Cell phones and driving: review of research. Traffic Inj Prev 7:89-106

13. Pöysti L, Rajalin S, Summala H (2005) Factors influencing the use of cellular (mobile) phone during driving and hazards while using it. Accid Anal Prev 37:47-51 
14. Hahn RW, Prieger JE (2006) The impact of driver cell phone use on accidents. J Econ Anal Policy Adv 6:1-37

15. Strayer DL, Johnston WA (2001) Driven to distraction: dual-task studies of simulated driving and conversing on a cellular phone. Psychol Sci 12:462-466

16. Haigney D, Westerman SJ (2001) Mobile cellular phone use and driving: a critical review of research methodology. Ergonomics 44(2):132-143

17. Goodman MJ, Tijerina L, Bents FD, Wierwille WW (1999) Using cellular phones in vehicles. Transp Hum Factors 1:3-42

18. Huang HF, Stutts JC (2003) The characteristics of cell phonerelated motor vehicle crashes in North Carolina. Transportation Research Board Preprints [CD-ROM]: Washington, D.D., TRB

19. McEvoy SP, Stevenson MR, McCartt AT, Woodward M, Haworth C, Palamara P, Cercarelli R (2005) Role of mobile phones in motor vehicle crashes resulting in hospital attendance: a case-crossover study. Br Med J 331:428-430

20. Bailey TJ (1994) The road safety implications of mobile phone use whilst driving: a short literature review. Report Series 4/94 (Brisbane: Office of Road Safety, South Australian Department of Transport)

21. Nunes L, Recarte MA (2002) Cognitive demands of hands-freephone conversation while driving. Transp Res Part F 5:133-144
22. Chang LC, Krosnick JA (2003) National surveys via RDD telephone interviewing vs. the internet: comparing sample representativeness and response quality. Ohio State University. http:// www.psy.ohio-state.edu/social/CSR-KN-HI.doc

23. Marshall RJ, Rodney TJ (1993) Analysis of case-crossover designs. Stat Med 12:2333-2341

24. Fairclough SH, Ashby MC, Ross T, Parkes AM (1991) Effects of handsfree telephone use on driving behavior. In Proceedings of the ISATA conference, Florencia, Italia, ISBN 0947719458

25. Wickens CD (1991) Processing resources and attention. In: Damos DL (ed) Multiple-task performance. Taylor \& Francis, London

26. Wilde GJS (1982) The theory of risk homeostasis: implications for safety and health. Risk Anal 2:209-225

27. Wilde GJS (1988) Risk homeostasis theory and traffic accidents: propositions, deductions and discussion of dissention in recent reactions. Ergonomics 31:441-468

28. Mikkonen V, Backman M (1988) Use of the car telephone while driving. Technical Report \# A39. Department of Psychology, Univeristy of Helsinki

29. Ishigami Y (2007) Is a hands-free phone safer than a handheld phone? In: BBCS/SCCC 17th annual meeting 